Article

\title{
Beyond Fires and Deforestation: Tackling Land Subsidence in Peatland Areas, a Case Study from Riau, Indonesia
}

\author{
Erlis Saputra ${ }^{1,2}$
}

1 Department of Human Geography and Planning, Faculty of Geosciences, University of Utrecht, Vening Meinesz Building, Princetonlaan 8A, 3508 TC Utrecht, The Netherlands; E.Saputra@uu.nl or erlissaputra@gmail.com; Tel.: +31-619328938

2 Department of Development Geography, Faculty of Geography, Universitas Gadjah Mada, Bulaksumur, Yogyakarta 55281, Indonesia

Received: 27 March 2019; Accepted: 25 April 2019; Published: 30 April 2019

check for updates

\begin{abstract}
Peatland plays an important ecological and economic role in many countries all over the world. At the same time, due to various human and non-human interventions, peatland is also a fragile ecosystem, which is currently facing severe problems, such as deforestation, fires, and peat subsidence. Peat subsidence is currently one of the most severe but least recognized issues. Because of its interconnectedness with other peatland problems, peat subsidence intensifies when there is a lack of proper interventions. In this paper, types of problems that arise along with and from peat subsidence and how various actors deal with it are going to be analysed. This paper illustrates an example from peatland areas in Indonesia and addresses two questions: (1) what kinds of problems are related to peat subsidence? In addition, (2) how do various actors deal with peat subsidence and what are the consequences of their interventions? Based on in-depth interviews with key persons from government institutions and NGOs, followed by focus group discussions with communities, analyses of policies, and desk study, this research discovered that peat subsidence is a hidden problem that is highly interconnected with other peatland problems that have caused severe physical-environment and socioeconomic impacts. While various actors have taken numerous interventions to deal with deforestation and fires, those concerning peat subsidence are still limited. Since dealing with peatland problems as a whole requires an ecosystem-based intervention, a more comprehensive approach is needed to manage peat subsidence.
\end{abstract}

Keywords: peatland; peat subsidence; the governments; nongovernmental organizations (NGOs); communities; Riau

\section{Introduction}

Peatland plays an essential ecological and economic role in many countries all over the world. While it only covers about 2.84 per cent of the world land area, i.e., about 423 million hectares, peatland stores approximately 10 per cent of global freshwater resources and more carbon than all forest biomasses of the world [1-3]. However, in recent decades, peatland has been destroyed by human and natural activities, which has created severe problems. Natural and human activities, such as climate change, agricultural exploitation, peat fires, and drainage systems have caused this degradation [4-6], leading to the loss of land cover, emission of carbon, loss of biodiversity and ecosystem, fires, and land subsidence [7-9].

Among peatland problems, peat subsidence is one of the most severe but least recognized issues $[3,10]$. It is triggered by a combination of the decomposition and compression of peat volume due to peat fires and massive growth plantations surrounded by canals [9,11-13]. The vast agricultural 
development that necessitates drainage has accelerated the drying out and decomposition process of organic matter, resulting in the sinking of peatland [5,9,14].

Over an extended period, peat subsidence triggers numerous problems. It releases a large amount of carbon dioxide [9], increases the potential for drought and flooding [11], decreases the storage of freshwater caused by saltwater intrusion [15], and ruins buildings, roads, and utilities [10]. It also generates economic losses and external costs [16]. Soon, it will increase the permanent loss of peatland [13]. Peat subsidence is a severe problem since it leads to other peatland problems (e.g., see $[5,9,10,12,17])$.

This paper analyses the types of problems that come with peat subsidence and the interventions of various actors to deal with it. To do so, two research questions are addressed. First, what kinds of problems are related to peat subsidence? This question is intended to understand the physical-environment and socioeconomic consequences caused by or triggered by peat subsidence. At the same time, this exploration is used to discover the relation between peatland problems. The second question is how do various actors deal with peat subsidence and the consequence of their interventions? This question discovers interventions taken by the government at different levels, nongovernmental organizations (NGOs), and communities to deal with peat subsidence and other problems. The information concerning impacts of their interventions is also expected. The extent to which peat subsidence has been a concern for the actors as well as links between such actors is also explored. There is ample and proven scholarly evidence showing the importance of disaster response in the context of rapid-onset or short-term disasters, e.g., earthquakes, tsunamis, flooding, landslides, hurricanes, and volcano eruptions [18-21]. In contrast, the discussion about responding to long-term disasters, such as land subsidence, is limited. This contributes to the gap in the debate of measures actors have taken to deal with peat subsidence within the context of complex peatland issues.

The presence of various actors and their collaboration in solving these land problems is highly debated. At the global level, the Sustainable Development Goals (UN-SDGs) was often used as a blueprint to improve the status of the land, by bringing the governance ideas to stimulate collective actions. The existence of actors along with their goals and strategies in a governance frame is a vital part of the success of SDGs [22]. Therefore, this paper contributes to this debate by providing an example of measures from various actors in dealing with peatland problems. Since the success indicators of the partnership in SDGs are still being developed, this paper is not intended to evaluate collaborative actions, but to discover the interest and dynamics of actors in peatland issues.

Using an example from Indonesia peatland, this paper answers the research questions through in-depth interviews, with policy evaluation, representatives from the actors, focus group discussions, and field research. Indonesia represents the fourth largest country with peatland in the world by holding about 56 per cent of tropical peatland [23]. At the same time, Riau peatland can represent peatland in Indonesia since it holds about 19.3 per cent of the total peatland, i.e., the second largest among other provinces [24]. Thus, this case study can characterize the complexity of peat subsidence worldwide.

This paper is organized into six sections. The next sections explain the theoretical framework followed by the data collecting process. Subsequent sections describe the complex consequences of peatland development and interventions of actors to deal with the problems. It ends with some discussions and conclusions.

\section{Land Subsidence, Complex Problems, and Actor-Centered Approach}

Land subsidence is a gradual settling or sudden sinking of the earth's surface due to a movement of earth materials [25]. It is a result of the compaction or consolidation of the inter-bedded layers of clay and silt within the aquifer system due to the intensive exploration of groundwater [26]. In the peatland area, it is caused by the combination of the decomposition and compression of peat volume [9,11-13]. The development of drainage, following the massive expansion of plantations in peatland, has been accelerating the drying out and decomposing of the organic matter that triggers peat subsidence $[5,9,14]$. 
The continuous sinking of peatland leads to severe consequences for peatland ecosystems and people (see $[9-11,13,15,16])$. Peat subsidence may trigger more complex problems since it leads to and is led by other peatland problems $[5,9,12,17]$. Even though its consequences are severe, peat subsidence is often ignored due to its gradual process. This lack of attention causes it to be known as a sleeping disaster $[10,25]$. This is also the reason research on measures taken by actors to deal with peat subsidence is still lacking. Thus, the understanding of responses from various types of actors to deal with these complex problems is needed to know the readiness of actors to deal with such problems.

In complex disaster and environmental problems, an actor-centered approach is considered an adequate approach since it puts various and multi-level actors into the center of the debate. This approach may help to understand various factors to deal with problems that originates from various actors [27]. It also considers actors interventions and measures from state and non-state actors as vital in dealing with a problem [28]. To illustrate this approach, the focus will be on three types of actors: the government, NGOs, and communities. The governments are vital actors in responding to disasters and environmental risks since they are the most responsible body to guarantee safety for citizens through proper policies and construction measures [29]. Governments can create a national system and legal framework to manage risks and promote sustainable risk management $[21,30]$. NGOs also play a critical role in reducing the risk of disasters through community-based disaster management, mediation, and advocacy [18]. The NGOs can cover for the weakness of the government in solving problems because of their particular knowledge of small level issues and their flexibility to deliver strategic solutions to communities, while the governments are mostly unwelcomed [31-33]. Through their specific abilities and experience, the initiatives from both actors might increase the ability to deal with disasters [34]. Furthermore, since communities own the problems and consequences of any interventions, it is necessary to understand that their roles and involvement in developing strategy and programs might also increase the opportunity to deal with the problems [35].

All actors are expected to tackle peatland problems, which are usually complex [12]. Peat subsidence, combined with other peatland problems, is complex since it involves various causal factors and triggers conflicts among actors concerning the nature of the problem and the beginning steps to find a solution. All problems will be analysed carefully using problem characteristics similar to Howes and Wyrwall [36] to see how complex the problems are (see Table 1). The understanding of the wickedness of the problems is needed to parse complex problems based on their characteristics and relationships. This framework will be applied by defining peat subsidence and other peatland problems with three characteristics. To understand such complexity, it is essential to engage actors involved in policy making and who have enough experience and knowledge of problems from the national down to the local scale.

Table 1. Characteristics of wicked problems.

\begin{tabular}{|c|c|}
\hline Characteristic & \\
\hline Problem formulation & $\begin{array}{l}\text { - No definitive formulation due to extreme complexity. } \\
\text { The problem is constantly evolving and is never completely resolved. } \\
\text { Any solution(s) may only be temporary. }\end{array}$ \\
\hline Interdependency & $\begin{array}{l}\text { - The problem is composed of and related to many different problems. All of } \\
\text { these different elements affect each other through a network of linkages. }\end{array}$ \\
\hline Solution set & $\begin{array}{l}\text { - Any solution causes feedback effects. The linkage between constituent } \\
\text { elements means that the total effect is difficult to ascertain. } \\
\text { A potentially infinite solution set exists. The merits of different solutions } \\
\text { are determined by the judgement of different stakeholders. }\end{array}$ \\
\hline
\end{tabular}


This research is about governance, which refers to a new process of governing society [37]. It contains activities of the governmental and non-governmental actors from multiple levels [38]. In this paper, governance includes rules, regulation, and policies of the actors. In analyzing the realities of the ground, this research will also give more attention to interest, interaction, and dynamics between the actors. Thus, an actor-centered approach is needed as it can analyse the dynamics and complex interactions of different actors, which cannot be done by another approach, such as an institutional approach [39]. It is in line with one of the strategies to deal with the wicked problems, i.e., collaborative strategies among actors whose power is dispersed [40]. The complete picture of the problems from the local to the broader scale is needed to be considered to successfully tackle the problems by involving all levels of governments and a range of NGOs [41].

The actor-centered approach is operationalized by first identifying actors involved in peatland issues, followed by explaining their interventions to deal with the problems. Diverse perspectives and the roles of various actors are important factors in this approach [42]. This paper explores different roles of the national, provincial, and local government; national and local environment and development NGOs; and local communities in dealing with peatland problems, including peat subsidence. In addition, the interactions and dynamics among these actors in building or improving measures will also be considered. The interactions might create two patterns of relationships, i.e., complementary or contradictory relations [21]. The exploration of the actors' interventions and interactions makes the actor-centered approach very suitable for application because it is set to facilitate mutual understanding and networks among the actors [42].

\section{Data Collection and Analysis Methods}

Data was collected using four methods: in-depth interviews with representatives of the actors, focus group discussions (FGD) with communities, evaluation of policies and documents of the actors, and field research. According to Yin [43], a case study qualitative method that combines several sources of evidence, such as open-ended interviews, documents and policies, and focus group interviews, is suitable to address the research questions since this method allows the researcher to gather complete and detailed information that is strictly related to the research aims. Furthermore, these data sources, i.e., in-depth interviews, FGD, and policy and document analyses, were used to strengthen the understanding and facts about peatland problem phenomena using a data triangulation principal [43]. Data triangulation was also used to prevent invalid information regarding a phenomenon that could come from multiple sources of data.

First, in-depth interviews, which were taken at the beginning of 2015 and the end of 2016, were held to collect information from the government and NGOs at the national and local level. To select interviewees, the government institutions and environmental and development NGOs in Indonesia and Riau Province were listed. From the list, those whose tasks were closely related to peatland and forest issues were chosen (see Table A1). In addition, the interviewed NGOs were also selected by considering the NGOs in Riau as well as those outside Riau but that work regularly in this province. Their spatial coverage (international, national, or local) and working focus were also considered. The local NGOs, which were selected from 158 NGOs, were prioritized since most of them have enough experience and knowledge of the local problem. A standard guideline was used during interviews to direct interviewees answering research questions. The types of peatland problems, problem interconnection, and interventions of actors to deal with such problems were asked. In some interviews, actors were represented by one or more high-level representatives. The interviews were conducted mostly in the offices of the actors. On average, the duration to finish one interview was about 60 to $90 \mathrm{~min}$. Phone interviews were used for actors that could not be reached in face to face interviews due to the distance or schedule constraints. 
Second, FGD with communities were held to discover problems of peatland at the local level and how the affected community responds to the issues. The on-the-spot FGD was focused on a locality in a particular district, Indragiri Hilir District, particularly Harapan Jaya Village, in which impacts of peat subsidence were massive, and the community has responded to some of the issues. The participants of the FGD, held in 2016, were representatives of various community group leaders, such as representatives among the fire care community, women, youth, and religious groups or leaders. In the FGD, a total of 30 group representatives were invited.

The in-depth interviews and FGD were recorded using an audio recorder with the agreement of the interviewees. The records were then translated into the transcripts of the interview. To analyse the transcripts, framework analysis was used [44,45]. Framework analysis describes and interprets different aspects of phenomena from cross-section data in a particular setting [45]. This analysis helps the researcher to manage a complex and large amount of data starting from data familiarization to data analyses [46].

Furthermore, to complete the information gathered from in-depth interviews and FGD, an analysis of policies and documents of the government and NGOs was also made. This analysis was done from the beginning of 2015 until the beginning of 2019 to gather sufficient information and anticipate the change of policies and documents. Various policies from the national, provincial, and local government regarding peatland and forest management, Spatial Planning, and disaster management and risk reduction were listed and summarized. Next, policies that were strictly related to peatland, forest, and disaster issues were studied more intensively, completed by information from official documents of actors, such as reports, newsletters, books, social media, and websites.

An effort to re-check the information gathered from mentioned methods and complete missing field research information was also conducted. Some information gathered from in-depth interviews, FGD, and analyses of policies and documents were re-checked through field research, especially in areas that have been particularly damaged, to discover the detailed and comprehensive status of land subsidence and measures taken by various types of actors. The field research, which was held in 2015 and 2016, was focused on five sub-districts that have been suffering from peat subsidence and other peatland problems for years, i.e., Tempuling, Enok, Tembilahan Hulu, Batang Tuaka, and Tembilahan. Thus, field research was mainly used to collect information at the local level.

\section{Results}

\subsection{Physical-Environment and Socioeconomic Issues Caused by Peatland Development}

Riau, located in Sumatra Island, Indonesia, holds about 3.87 million hectares of peatland, equal to one-fifth of the total peatland in Indonesia and three-fifths of total peatland in Sumatra Island [24,47]. Of these, about 86.8 per cent are categorized as moderately deep and deep peatland, i.e., the depth is more than two meters [47] (see Figure 1). In this province, districts and cities in the northern and eastern part, i.e., Indragiri Hilir, Indragiri Hulu, Kepulauan Meranti, Pelalawan, Siak, Bengkalis, Dumai, and Rokan Hilir manage more than half of the total peatland. 


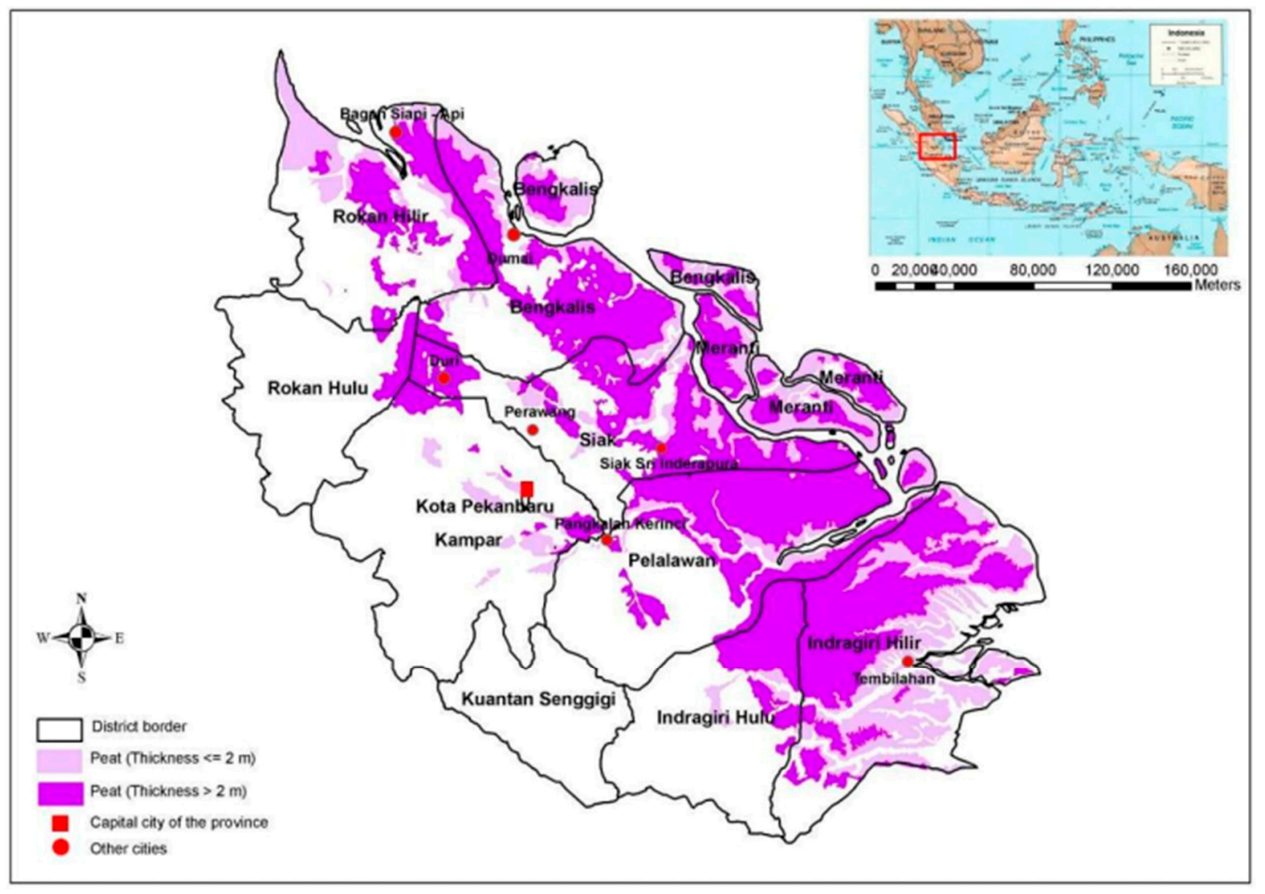

Figure 1. Distribution of peatland in Riau (Source: Center for Soil and Agroclimate Research, 2011, in Susanti and Burgers [48]).

Since 1982, Riau peatland has been over-exploited for various non-forestry purposes, such as plantations [49]. The massive peatland development was a response to the demand for peatland commodities and the increase in foreign and local investment in peatland areas [50]. The plantation is dominated by private and smallholder oil palm, timber, and coconut palm estates. Oil palm in Riau is growing the most compared to other provinces in Indonesia since this province is the target area for oil palm plantation development to fulfil the global demand [51]. By 2017, oil palm plantations had covered about 2.5 million hectares, of which about 40.66 per cent is owned by private estates [52]. Besides oil palm, Riau also contributes to 72.85 percent of total pulp and paper production and leads coconut plantations in Indonesia, with about 515 thousand hectares [53,54]. The combination of the growth of these plantations has caused severe problems, such as deforestation, fires, and peat subsidence, followed by a decrease in the economic status of affected people [7-9,55].

\subsubsection{Deforestation}

Deforestation has been spreading all over the province and has become a serious issue due to its massive amount and speed of occurrence (Figure 2). Uryu et al. [49] record that within 25 years, about 65 per cent of land cover has been lost. Between 1982 and 2007, about 1.83 million hectares of peatland (i.e., equal to 57 per cent of total peatland) had been converted to non-forest purposes [56]. This vast deforestation was mainly driven by a rapid expansion of oil palm estate and pulp and paper industries [50]. In four years, between 2008 and 2012, for instance, oil palm plantations had covered wider areas of peatland, i.e., from 29 per cent to 70 per cent of total peatland respectively $[49,57]$. This also decreased the percentage of forest coverage, from about 63 per cent to about 22 per cent [57]. Areas covered by forest were even smaller due to the massive growth of pulpwood plantations [49]. Even worse, a policy of the government that provided an incentive for oil palm and pulpwood mills and the lack of capacity and the corruption at the local level government caused increased deforestation $[14,36]$. 
The massive deforestation has triggered severe problems. It has caused a vast loss of peatland and biodiversity, emission of carbon, decomposition of deep peatland, and the decrease of rice fields $[24,51,58]$. The consequences could become worse since the Government of Indonesia (GoI) set a target to increase the use of biofuel and triple the width of timber plantation by 2030 [59].

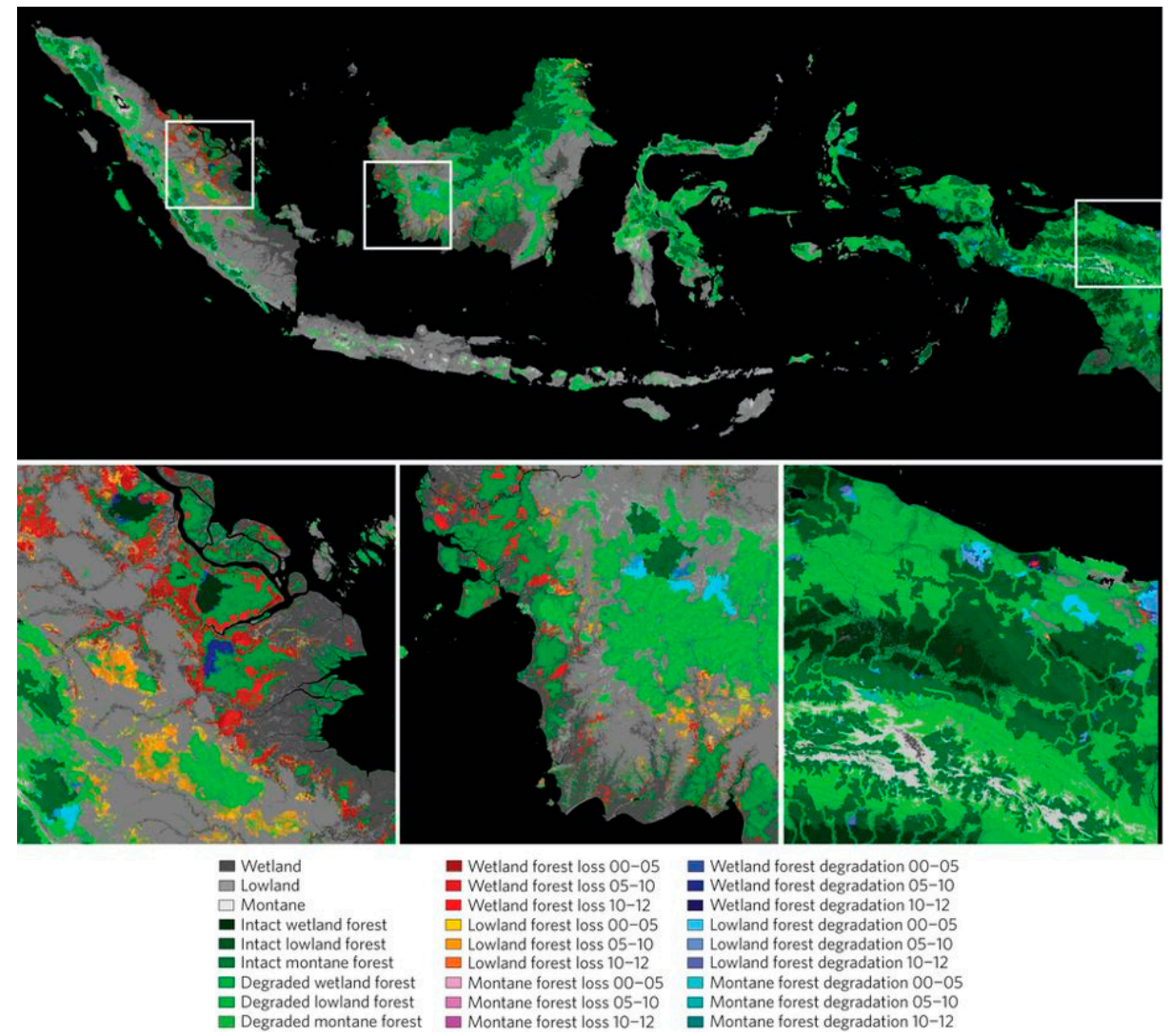

Figure 2. Deforestation in Riau (left below). The speed and coverage of deforestation are highest among other areas in Indonesia (Source: Margono et al. [60]).

\subsubsection{Fires}

Riau is a province with the most frequent fire events in Indonesia [61]. The fires are mostly triggered by human activities [8]. The development of plantations by clearing the land using fires was one of the triggers of bigger fires since the peatland was easily burnt [14]. This type of land preparation was found in small-scale land clearance activities by local farmers and in large scale private companies [62]. The development of canals along the peat bog surrounding the plantation also decreased the surface level of peat and dried soil out from the peat, which caused the area to be prone to fires [49].

In Riau, numerous large-scale fires had been recorded since the beginning of the 1980s [14]. The mega-fires of 1997-98 were the biggest fire events in Riau (and also in Indonesia) due to their massive impact on communities-about 10 per cent of the total population in Riau suffered health problems [63]. During this event, there were about 5870 hotspots in Riau (equal to 23 per cent of the total hotspot in Sumatera), of which one-third of them were located on oil palm plantations [64]. The mega-fires also caused severe air pollution, damaged plantations, and pushed the local government to close schools, offices, and airports. After this event, fires were increasingly frequent. Between 1997 and 2007, one-third of 72,000 active hotspots in Riau had been burnt at least once [49]. Then, fires happened in 2014 that burned about 11 per cent of peatland [65], followed by another big fire event in 2015 burned about 169,119 hectares of forest and land [66]. Recently, in 2018, fires had burned about 5776 hectares of land [67]. 
All fire events had caused severe physical and socioeconomic impacts. The issues included loss of property, cross-boundary haze, air pollution, loss of forest and peatland ecosystem, carbon emission, peat subsidence, and some people were even killed $[14,49,66,68,69]$. The fires should grab the attention of related actors since the current fire management system only focuses on firefighting, rather than fire prevention [14].

\subsubsection{Peat Subsidence}

The development in peatland areas has also triggered peat subsidence. Some areas sink about 4 to $6 \mathrm{~cm} /$ year $[9,10]$. Peat subsidence is caused by oxidation, shrinkage, and compaction of peatland, triggered by two factors, i.e., peat fires and the development of big or small-scale drainage around plantations $[9,12,14,17]$. The fires increased the oxidation and degraded peatland ecosystems, while the drainage accelerated the drying out and the decomposing of organic matter [5,14]. Land clearing processes and drainage development surrounding plantations also increased the oxidation, which accelerated the sinking, especially in the early stages of plantation development [70].

Peat subsidence led to various consequences. It caused a massive and continual loss of carbon [5], triggered the infiltration of saltwater [17], and ruined oil and coconut palms, i.e., tilting, drowning, and dying $[10,12]$. As an indirect impact, during the rainy season, peat subsidence expanded flooding in the agricultural areas, which increased the costs to the agricultural sector [9]. At the household level, it damaged houses (i.e., cracking, sinking, and leaning) and undermined income earning capacity of affected households [10,55]. Peat subsidence is a serious issue since it needs a complete restoration through methods like maintaining the level of groundwater level and reducing subsidence through drainage and water conservation and management [71].

Considering the three mentioned issues, it is clear that peatland development has caused various problems. Even though the development of peatland for plantations, for instance, may lead to significant short-term economic profit for local people (smallholders), private estates, and local government, it also may trigger long-term costs for physical-environment and socioeconomic status of peatland ecosystems and people (see Figure 3). All problems are interrelated and driven by various sources. Some of them have a causality linkage. The deforestation caused by the construction of drainage surrounding the estates has accelerated peat subsidence and increased the risk of fires, while fires have increased peatland oxidation, which caused peatland sinking. On the contrary, the treatment on drivers of peat subsidence, such as proper measures to keep the balance of the water table in the plantation, will minimize fires. This interconnectedness must receive serious attention since each problem is intrinsically linked to not only various drivers but also consequences at a small and large scale. Therefore, it calls on actors, such as the government from all levels, environmental and development NGOs, and communities to take interventions to solve the problems.

\subsection{The Responses of Various Actors to Peat Subsidence}

The issues mentioned in Section 4 need to be resolved. Actors, namely the national, provincial, and local government, environmental and development NGOs, and communities tried to deal with the problems by taking various interventions based on their capacity and understanding of the problems. 


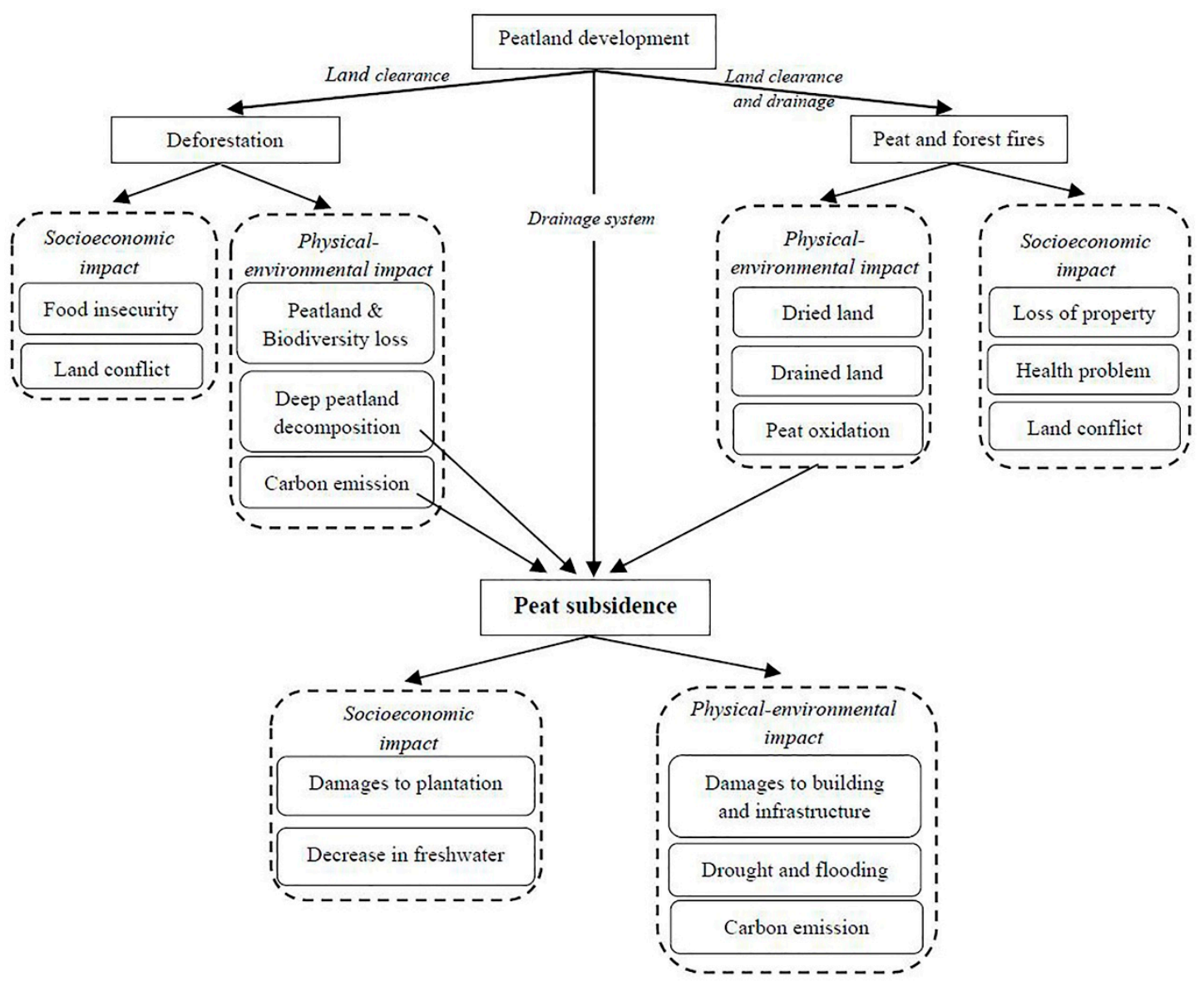

Figure 3. The relationship among peatland problems.

\subsubsection{The Responses of the Government}

Since peat subsidence happens gradually, it is recognized mostly from its impacts. In Riau, as the impacts have just been discovered (such as severe damage to plantations), peat subsidence is still not a top priority of the government. Peat subsidence research has only begun to intensify in the last two decades. Thus, measures to deal with it have been limited. The government from various levels has focused more on deforestation and fire issues.

One of the crucial measures of the national government in managing peatland has been the forest moratorium policy [72]. The moratorium aims to postpone formal licenses for companies, prohibit land clearing activities for plantation development, and oblige every business activity to allocate parts of their concession areas for conservation purposes. The moratorium was issued three times, i.e., a two-year moratorium on new concessions in primary natural forest and peatland areas (2011), a two-year moratorium on the protection and management of peat ecosystems (2015), and a three-year moratorium of postponing and evaluating the development of oil palm plantations (2018). The latest moratorium that includes activities to verify cultivation rights on land (Hak Guna Usaha, or HGU) is directed to solve peatland problems driven by planting activities. However, this aim is questioned since the moratorium was only addressed to activities in new concessions while those in permitted concessions were still allowed.

In addition, the national government tried to manage peatland by allocating land to accommodate its protection and production function through National Spatial Planning (RTRWN). RTRWN aims to increase the productivity of the areas and protect them from environmental damages. At the provincial and district/city government levels, policies and strategies in RTRWN are expected to be accommodated in Spatial Planning, Detailed Spatial Planning, and Zoning Regulation. In Riau, the provincial government issued Spatial Planning (RTRW Riau) 2018-2038, incorporating protected 
and production areas. It is intended to manage problems of lands in the entire province, including deforestation and other peatland problems. However, numerous academics and NGOs doubt the RTRW Riau can solve peatland problems because it did not consider various issues that have been the triggers of land conflicts, e.g., company-community estate borders and holding zone allocation.

Not only had they taken measures regarding deforestation, the national and provincial government also issued various measures to prevent and fight fires, which receives the most attention when compared to other problems. For instance, (former) National REDD+ Agency along with universities initiated a seasonal fire early warning system (i.e., the Fire Risk System or FRS) and trained the local government in Riau to recognize fire risk [14]. Regarding a more technical solution, in 2014, the Riau Government and the Indonesian National Board for Disaster Management (BNPB) obliged every plantation around the drained peatland to construct a canal block system to keep the balance of the water table to minimize risk of fires. However, this solution failed because the fires reoccurred in the following year [66].

Other government institutions at the national, provincial, and local level had also taken measures to deal with fires. For instance, the Provincial Board for Disaster Management (BPBD Riau), supported by BNPB, reinforced a Task Force for Forest and Land Fires (Satgas Karhutla) to quickly respond to fires. At the local government level, the Government of Pelalawan, Rokan Hilir, Siak, and Kepulauan Meranti District regularly invited vulnerable communities to various trainings and meetings held by the government. Also, Siak Government named their district a 'green district', which was directed to maintain forest areas by keeping deep peatland as the protected zones. To date, in 2018, Rokan Hilir Government initiated the Regional Action Plan for Land and Forest Fires (RAD Karlahut) to prevent fires in peatlands.

Furthermore, community-based fire prevention was also a concern of various governments. For instance, following the 'green district' initiative, the Government of Siak introduced a community-based program called Community-Based Forest Fire Management (CBFFM). Also, the Ministry of Environment and Forestry (MoEF) initiated a Fire Care Community (MPA) to monitor and prevent forest fires at the community or village level. In some areas, MPAs had been enhanced by the local government or private sector to be a Fire Care Village (DPA). This means that the responsibility to deal with fires has been improved from the community to village government. The establishment of MPA and DPA inspired some companies, such as Asian Pulp and Paper (APP) and Riau Andalan Pulp \& Paper (RAPP) to support the government's program by allocating money for DPAs around their concessions or develop new DPAs initiated by the companies [73,74]. Both MPA and DPA were tasked with increasing the community's awareness of and ability to prevent fires. However, the effectiveness of this community-based program to avoid fires was still questioned since their activities were focused more on fighting existing fires than preventing its drivers [75].

Amid the mentioned policy measures, unfortunately, there was no single policy concerning peat subsidence. There was only a local government program that promised to deal with peat subsidence. In 2015, the Government of Indragiri Hilir introduced a Trio Tata Air program aiming to control the balance of water levels in sinking coconut plantations by repairing drainage leakage and constructing canal blocks. This initiative was expected to save about 10 thousand hectares of the plantation from damages caused by sinking and flooding. Even though it was promising, the lack of continuous funding restricted the implementation, resulting in continuous damage to the plantation and sinking of peatland.

At the beginning of 2016, the Peatland Restoration Agency (BRG) was established to coordinate and facilitate activities to restore peatland in seven provinces, including Riau. In Riau, BRG has been slowly delegating restoration activities to the Regional Peat Restoration Teams since 2018 (Tim Restorasi Gambut Daerah, or TRGD). To ensure ideas from various actors are covered, BRG and TRGD involve government institutions, NGOs, national and international donors, academia, private sectors, and local communities in their activities. 
By 2020, BRG expects to restore about 800 thousand hectares in Riau within Peatland Hydrological Unit (PHU) through three approaches (3R), i.e., rewetting, revegetation, and revitalization. These approaches have been started by BRG by giving priority to the rewetting measures. The rewetting was applied by developing canal blocks and deep wells in districts or PHU where peatland has been extremely damaged. By 2017, BRG, in total, had constructed 309 canal blocks in 24 villages and 400 deep wells in 8 villages in various districts [76]. BRG had developed 34 and 38 canal blocks, respectively, in PHU Pulau Tebing Tinggi and PHU Pulau Padang, Kepulauan Meranti District. It built 41 canal blocks in three villages in Dumai City and had developed 50 deep wells in Rimbo Panjang Village in Kampar District. Then, in 2018, another 108 canal blocks and 34 deep wells in Kepulauan Meranti and 47 canal blocks in Dumai City were constructed [76,77]. Furthermore, some revitalization and revegetation activities were also launched, which usually were done almost simultaneously. For instance, BRG initiated the economic revitalization programs for communities in Kepulauan Meranti District by promoting paludiculture and allocated two hectares of areas to be revegetated [76]. BRG also trained local communities to increase their economic status through an activity to intensify the value of fishery commodities in peatland and participatory revegetation. To ensure the economic revitalization is in line with revegetation efforts, BRG obliged local people to plant local commodities, e.g., sago, pineapple, coconut, and jelutong in the areas that have been restored. Then, to ensure the sustainable involvement of the community in BRG's activities, the 3R approach was continued by establishing a Peatland Care Village (Desa Peduli Gambut, or DPG). By 2017, BRG had promoted 11 DPG where programs initiated by BRG were built up by the local community or even NGOs and the private sector [76].

\subsubsection{The Response of NGOs}

For decades, environmental and development NGOs at the national and local level have been playing crucial roles in managing Riau peatland. Some of them have even expanded their tasks from a single social movement into experience and knowledge-based activities, such as policymaking assistance and knowledge-sharing initiatives.

Among all these measures, advocacy was still the primary activity in keeping the sustainability of peatland. The advocacies were intended to deliver protests and increase awareness of peatland issues in governments-especially provincial and local governments-the private sector, and communities. The issues and ways of delivering ideas were different among NGOs, which were determined by their working locality and area of focus. Some environmental NGOs, such as Wetlands International Indonesia, Greenpeace Indonesia, Indonesian Society for Disaster Management (MPBI), and WWF Indonesia advocated to the national government and multinational companies regarding deforestation and peat fires through frequent campaigns. Wetlands International Indonesia also worked with the bank and industry certification agency to increase awareness of investors concerning sustainable peatland. WWF Indonesia promoted Roundtable for Sustainable Palm Oil (RSPO) certification to palm oil industries to encourage the sustainable growth and use of oil palm commodities.

Moreover, for years, local environmental NGOs have been focusing their advocacy on local issues related to peat fires, deforestation, and estate development. Walhi Riau, Jikalahari, Hutan Riau, YMI (Yayasan Mitra Insani), and LSM Rupari frequently delivered campaigns regarding forest cover loss caused by big-scale oil palm and pulpwood plantations, land conflicts between communities and companies, and the weakness of law enforcement for actors and corruptors behind the frequent forest and peatland fires. Furthermore, Jikalahari also delivered their thoughts in various national and international forums to keep issues of deforestation and fires as a global concern. Then, various environmental NGOs also expanded their advocacy to target younger people and students by placing their ideas in booklets, newsletters, books, social media, or websites. Unfortunately, peat subsidence appeared as a supplement and a small part of peat fires and deforestation debates.

To support their advocacy activities, some NGOs also worked in practical ways. The inability of their campaigns and protests to attract the government and private sector activities triggered some national and local environmental NGOs to work directly with other actors at small-scale activities. 
For instance, Greenpeace Indonesia established a voluntary Forest Fire Prevention Team (Tim Cegah Api) to detect and fight fires. Walhi Riau, Hutan Riau, and Jikalahari also worked to identify hot spot distributions and delivered information to the governments, communities, and MPAs. Jikalahari, YMI, and Walhi Riau also tried to prevent forest fires and ecosystem damages by actively participating in a Tesso Nilo Ecosystem Revitalization project in Pelalawan, Kuantan Singingi, and Kampar District. Furthermore, since 2013, YMI has been working with a local community in Harapan Jaya Village, Indragiri Hilir District to prevent fires through community-based peatland management and community economic empowerment. Along with the community, they initiated a Village Participatory Contour Map and a Grand Design of Village Water Management, developed fire early warning systems, and built demonstration plots of small-scale oil palm plantations.

In the last few decades, NGOs have increased their knowledge of and experience in peatland management. They have been supported by the openness of the national and local governments to NGO involvement, and some environmental NGOs assisted such governments in designing policies and programs. Walhi Riau, Jikalahari, Hutan Riau, Walhi Indonesia, Wetlands International Indonesia, and Greenpeace Indonesia, for instance, were repeatedly involved in designing Spatial Planning and peatland restoration agendas. They regarded the meetings as opportunities to push the idea of sustainable peatland management into the governments' policies and programs. The involvement of NGOs was important to support the lack of government capacity to collect information at the community level. To some extent, their information was key to the local government and communities initiating particular programs. For example, Siak Government initiated a 'green district' program, which was supported by Walhi Riau, Jikalahari, YMI, and Yayasan Elang, while villagers and village governments in Bengkalis District, helped by Jikalahari, issued a Village Regulation on Water Management and Fire Prevention, which then was formalized by the local government [78].

Furthermore, some development and environmental NGOs have also inspired the government and affected people to start taking measures through training and capacity building activities. For instance, at the national level, YPB (Yayasan Pembangunan Berkelanjutan) conducted training on sustainable development and disaster management for leaders from the government institution, community, academia, and other stakeholders. At the local level, Hutan Riau, Walhi Riau, YMI, Greenpeace Riau, and Jikalahari trained local government officers and communities in Siak, Kepulauan Meranti, Pelalawan, Indragiri Hulu, and Indragiri Hilir District to identify the degraded peatland and the hotspots and fire distribution as well as to manage canals around plantations through a canal block system. WWF Indonesia trained independent oil palm smallholders in Kuantan Singingi District to increase their knowledge of sustainable palm oil [79].

Peat subsidence also undermined the income earning capacity of affected people [55], so some NGOs offered activities to increase income capacity and income source variety of those affected. Wetlands International Indonesia and Jikalahari proposed a community-based planting system, 'paludiculture', which combined local commodities with non-peat-based income sources, such as livestock. The 'paludiculture' could increase people's income and also delay peat subsidence [80]. Additionally, YMI facilitated affected people of Tempuling sub-district in Indragiri Hilir to increase the value of coconut by producing coconut-based cooking oil. Thus, these extra income generators are expected to increase the economic capacity of affected people.

All in all, environmental and development NGOs had taken various measures to deal with peatland problems. However, only some of them were designed with peat subsidence as the main concern. The lack of knowledge of peat subsidence, supported by their priority to deal with more obvious problems like fires, were reasons the NGOs neglected peat subsidence as their top priority. The gradual process of peat subsidence was another reason, as it seemed like a hidden problem and a minor issue. Therefore, most NGOs argued that quick responses were not yet needed. This assumption was worsened because most local environmental NGOs were struggling to maintain sustainable funding, which pushed them to work on regular activities instead of peat subsidence. 


\subsubsection{The Responses of Communities}

Communities, which are affected by peatland problems and measures taken by external actors, also took to action. They had tried to deal with peat subsidence in their surrounding areas by focusing mainly on two measures, i.e., managing canals and dealing with fires. Even though the measures were infrequent and small in the coverage area (village scale), their interventions indicated that they were aware of such issues.

Their measures were categorized into measures that were initiated by themselves and those that were developed by external actors, which then were improved or taken over by the people. Activities to rehabilitate and normalize canals were common measures initiated by communities. The oil and coconut palm plantations had dried out due to canals drying out, and had caused improper growth or death of the palms. The damage had decreased the income of affected people [55]. Therefore, to avoid a bigger loss, communities rehabilitated the canals by patching the leakages to maintain depth and managing the water table balance in plantations using a traditional canal block. At the community scale, these measures could prevent the damage from becoming worse. However, in some cases, the establishment of private oil palm estates near the villages had destroyed the smallholders' canal system since they were not connected well with those of private estates. Not only had they taken measures to deal with current problems, but communities also had tried to prevent the problems. Through village governments, locals also issued a Village Regulation on Forest and Land Fires Prevention, which aimed to build community-based fire prevention and a self-control mechanism among communities by arranging punishment points for people who burn their land and then trigger fires in others' land. Since the establishment of this regulation, fires caused by community activities could be minimized. However, fires from private estate activities could not be prevented.

Communities also continued and improved upon measures established by the national and local government or environmental NGOs. Some measures that required a particular skill were handed over to communities after some training in capacity building. For example, YMI designed a participatory contour map to assist communities to design canal block systems and initiated a grand design of water management to provide communities with strategies of managing water and canals surrounding plantations. Now communities slowly enhance the map through the latest data gathered from independent surveys to maintain the canals block system. They also combine programs arranged by MPA with the village regulations on fire prevention. According to communities, this combination has enhanced the success in preventing fires.

The interventions of governments, NGOs, and communities addressed different peatland problems, but mostly concerning fires (Table 2). Some local environmental NGOs had also begun working collaboratively with other NGOs or with the government, mostly the local government, to initiate measures. The collaborative work among NGOs was formed due to the mutual issues and targeted areas, while their collaborative work with the government was triggered by their need to share both knowledge and experience. Most of the measures were taken by a collaboration of two or three types of actors. The measures that involved more than a single actor could be originated from ideas of a particular actor or combined actors that were executed together. Therefore, this section shows that the measures had formed and increased interactions and dynamics between various types of actors. 
Table 2. Summary of interventions of the government, NGOs, and communities to deal with peatland problems in Riau.

\begin{tabular}{|c|c|c|c|c|c|}
\hline \multirow[b]{2}{*}{ Intervention } & \multirow[b]{2}{*}{ Involved Actor(s) } & \multicolumn{3}{|c|}{ Related Issue } & \multirow{2}{*}{$\begin{array}{l}\text { Scale(s) of } \\
\text { Intervention }\end{array}$} \\
\hline & & Deforestation & $\begin{array}{l}\text { Peat and } \\
\text { Forest Fires }\end{array}$ & $\begin{array}{c}\text { Peat } \\
\text { Subsidence }\end{array}$ & \\
\hline \multicolumn{6}{|l|}{ A. Policy and non-construction measures } \\
\hline $\begin{array}{l}\text { (1) Allocating protected peatland } \\
\text { areas in Spatial Planning }\end{array}$ & $\begin{array}{l}\text { Bappenas, Provincial and } \\
\text { local government, Walhi } \\
\text { Indonesia, Greenpeace } \\
\text { Indonesia, Wetlands } \\
\text { International Indonesia, } \\
\text { Bappeda, Walhi Riau, } \\
\text { Hutan Riau, Jikalahari }\end{array}$ & +++ & ++ & & $\begin{array}{l}\text { National, } \\
\text { provincial, and } \\
\text { local }\end{array}$ \\
\hline $\begin{array}{l}\text { (2) Designing an action plan to } \\
\text { prevent forest and land fires }\end{array}$ & Riau Government & & +++ & & Province \\
\hline $\begin{array}{l}\text { (3) Designing and implementing a } \\
\text { disaster management policy }\end{array}$ & $\begin{array}{l}\text { BNPB, BPBD } \\
\text { Kabupaten/Kota, MPBI }\end{array}$ & & +++ & & $\begin{array}{l}\text { National and } \\
\text { local }\end{array}$ \\
\hline $\begin{array}{l}\text { (4) Protecting deep peatland by } \\
\text { issuing protected zones through the } \\
\text { Green District program }\end{array}$ & $\begin{array}{l}\text { Local government, Walhi } \\
\text { Riau, YMI, Jikalahari }\end{array}$ & +++ & ++ & & Local \\
\hline $\begin{array}{l}\text { (5) Oblige smallholders and private } \\
\text { estates to construct canal block } \\
\text { systems }\end{array}$ & BNPB & & +++ & ++ & Local \\
\hline $\begin{array}{l}\text { (6) Campaigns on deforestation, } \\
\text { fires, and peatland restoration }\end{array}$ & $\begin{array}{l}\text { Walhi Indonesia, } \\
\text { Greenpeace Indonesia, } \\
\text { WWF Indonesia, Wetlands } \\
\text { International Indonesia, } \\
\text { Walhi Riau, Greenpeace } \\
\text { Riau, Hutan Riau, YMI, } \\
\text { LSM Rupari, Jikalahari }\end{array}$ & +++ & ++ & + & $\begin{array}{l}\text { National and } \\
\text { local }\end{array}$ \\
\hline (7) Offering RSPO certification & WWF Indonesia & +++ & & ++ & National \\
\hline $\begin{array}{l}\text { (8) Designing village contour maps } \\
\text { for canal development }\end{array}$ & $\begin{array}{l}\text { Village government, YMI, } \\
\text { communities }\end{array}$ & & ++ & +++ & Community \\
\hline $\begin{array}{l}\text { (9) Mediating community-company } \\
\text { land conflicts }\end{array}$ & $\begin{array}{l}\text { Walhi Riau, Hutan Riau, } \\
\text { LSM Rupari }\end{array}$ & +++ & ++ & & Local \\
\hline (10) Sharing peatland-based data & $\begin{array}{l}\text { Jikalahari, Walhi Riau, } \\
\text { Hutan Riau }\end{array}$ & +++ & ++ & + & $\begin{array}{l}\text { National, } \\
\text { provincial, } \\
\text { local, and } \\
\text { community }\end{array}$ \\
\hline (11) Pushing law enforcement & $\begin{array}{l}\text { Jikalahari, Walhi Riau, } \\
\text { Greenpeace Indonesia, } \\
\text { Walhi Indonesia }\end{array}$ & ++ & +++ & & $\begin{array}{l}\text { Local and } \\
\text { national }\end{array}$ \\
\hline $\begin{array}{l}\text { (12) Initiating a village regulation } \\
\text { on water management and fire } \\
\text { prevention }\end{array}$ & $\begin{array}{l}\text { Jikalahari, YMI, village } \\
\text { government and } \\
\text { communities }\end{array}$ & & +++ & +++ & Community \\
\hline $\begin{array}{l}\text { (13) Training for sustainable } \\
\text { development and disaster } \\
\text { management }\end{array}$ & YPB & +++ & & & National \\
\hline $\begin{array}{l}\text { (14) Training in increasing peatland } \\
\text { issue awareness for private sector }\end{array}$ & $\begin{array}{l}\text { Wetlands International } \\
\text { Indonesia }\end{array}$ & +++ & ++ & + & $\begin{array}{l}\text { National and } \\
\text { local }\end{array}$ \\
\hline $\begin{array}{l}\text { (15) Training to identify degraded } \\
\text { land for local government and people }\end{array}$ & $\begin{array}{l}\text { Walhi Riau, Hutan Riau, } \\
\text { Jikalahari, YMI }\end{array}$ & ++ & +++ & + & Local \\
\hline $\begin{array}{l}\text { (16) Initiating workshops in } \\
\text { peatland restoration }\end{array}$ & $\begin{array}{l}\text { Wetlands International } \\
\text { Indonesia, Jikalahri }\end{array}$ & + & +++ & ++ & Local \\
\hline $\begin{array}{l}\text { (17) Providing funding through } \\
\text { IPPF program }\end{array}$ & $\begin{array}{l}\text { Wetlands International } \\
\text { Indonesia }\end{array}$ & & +++ & + & Community \\
\hline \multicolumn{6}{|l|}{ B. Construction/applied measures } \\
\hline $\begin{array}{l}\text { (1) Restoring peatland through } \\
\text { rewetting, revegetation, economic } \\
\text { revitalization approach }\end{array}$ & $\begin{array}{l}\text { BRG, WWF Indonesia, } \\
\text { Wetlands International } \\
\text { Indonesia, Walhi Riau, } \\
\text { Jikalahari }\end{array}$ & & +++ & ++ & $\begin{array}{l}\text { National. } \\
\text { Provincial, } \\
\text { Local }\end{array}$ \\
\hline \multicolumn{6}{|c|}{$\begin{array}{l}\text { (2) Fighting fires by Establishing } \\
\text { Fire Care Community (MPA) and Fire }\end{array}$} \\
\hline Care Village (DPA), reinforcing Satgas & BNPB, MoEF, Riau & & & & Provincial, \\
\hline $\begin{array}{l}\text { Karhutla, designing RAD Karlahut, } \\
\text { initiating the CBFFM program } \\
\text { (Initiating community-based forest } \\
\text { fire programs) }\end{array}$ & $\begin{array}{l}\text { Government, BPBD Riau, } \\
\text { local government }\end{array}$ & & +++ & & $\begin{array}{l}\text { local, and } \\
\text { community }\end{array}$ \\
\hline $\begin{array}{l}\text { (3) Establishing Peatland Care } \\
\text { Village (DPG) }\end{array}$ & BRG & & +++ & ++ & Local \\
\hline $\begin{array}{l}\text { (4) Initiating a Trio Tata Air } \\
\text { program to rehabilitate plantations }\end{array}$ & Local government & & & +++ & Local \\
\hline $\begin{array}{l}\text { (5) Establishing Forest Fire } \\
\text { Prevention Team }\end{array}$ & Greenpeace Indonesia & & +++ & & Local \\
\hline $\begin{array}{l}\text { (6) Initiating 'paludiculture' } \\
\text { planting system }\end{array}$ & $\begin{array}{l}\text { Wetlands International } \\
\text { Indonesia, Jikalahari, BRG }\end{array}$ & & +++ & ++ & Community \\
\hline $\begin{array}{l}\text { (7) Involvement in Tesso Nilo } \\
\text { Ecosystem Revitalization }\end{array}$ & $\begin{array}{l}\text { Walhi Riau, Jikalahari, } \\
\text { YMI }\end{array}$ & ++ & +++ & & Local \\
\hline $\begin{array}{l}\text { (8) Empowering economics of } \\
\text { local community }\end{array}$ & YMI & & +++ & ++ & Community \\
\hline $\begin{array}{l}\text { (9) Rehabilitating and } \\
\text { normalizing canals }\end{array}$ & $\begin{array}{l}\text { Village government, YMI, } \\
\text { communities }\end{array}$ & & ++ & +++ & Community \\
\hline
\end{tabular}

Note: the amount of ' + ' reflects the degree of actors' priority to the issue; Source: Data analyses (2016). 


\section{Discussion}

This paper analyses the types of problems that come with peat subsidence and interventions of various actors to deal with it by addressing two questions: (1) what kinds of problems are related to peat subsidence? In addition, (2) how do various actors deal with peat subsidence and what are the consequences of their interventions? The following sub-sections discover the severity of peatland problems by explaining complex consequences of the problems and the relationships among them, as well as numerous interventions taken by various actors to deal with such issues, along with their consequences.

\subsection{How Severe is the Problem of Peat Subsidence in Riau?}

This paper shows that many peatland areas in Riau have been experiencing severe peat subsidence and other peatland problems. Peatland development is the main trigger of deforestation, fires, and peat subsidence, which are interrelated (see Figure 3). Peat subsidence could be triggered or worsened by other problems. Deforestation and fires could accelerate peat subsidence. The decomposition of peat soil and emission of carbon that followed deforestation and the development of drainage canals could trigger the sinking $[9,12,14,17]$. At the same time, fires that caused peat oxidation had caused the sinking to increase even faster [5,14].

These problems had also driven numerous physical-environment and socioeconomic consequences for peatland and affected people. One of the serious consequences was the loss of peatland ecosystem and biodiversity. Peatland is known as a scarce resource that is difficult to be renewed because most of its compositions are organic soil. Once the peatland has been damaged, it has a low possibility of being restored. The drained peatland also triggers various indirect impacts, such as fires and a decrease in plantation productivity. From the economic aspect, the intensive development of peatland had threatened its sustainable economic use. Indeed, the development of peatland could increase the income of smallholders such as from estate development, but it also increased food insecurity by decreasing the food crop field [48]. Peatland development also triggered social conflict. For instance, in Riau, Scale Up [81] found about 631 land conflicts between communities and companies in the last decade, which killed 19 people. As one problem can be a symptom of others, peatland development can trigger or create more complicated problems.

The interrelation between problems and the severity of their consequences could be illustrated by characteristics of wicked problems from Howes and Wyrwall [36].

\subsubsection{Problem Formulation}

Considering the problems in the Riau peatland, these issues originate from complex drivers and scales of a fundamental problem. Common causes include an increase of estate growth in districts where peatland is prone to damage, inappropriate government strategies in accommodating how peatland development can generate income, and the lack of knowledge of local government and communities of the causality relationship among peatland problems. The lists of these substantial drivers will grow depending on the scale interpretation of the problem. The causes at a local level will be different from those at the regional or national level.

Due to the complexity and interrelationship of the problems, the interpretation of the issues from different actors is dissimilar. In our case, there is no definitive comprehensive problem formulation by all actors. To start issuing policies and taking measures, peatland status must be monitored repeatedly by each actor using their resources and capacity, resulting in, again, a different interpretation of the problems. Consequently, measures taken were mostly partial and could not fit the entire problem. The measures only solved some of the problems, which were only effective temporarily. Therefore, the problems will still stand and even worsen. 


\subsubsection{Interdependency}

In this case, the problems are linked to many drivers and consequences. Because of their causality relationship, any interventions made for one problem will influence others. It is inarguable that peatland development, e.g., oil palms estates, could increase the income of local people, private sectors, and the provincial and local government. For the provincial and local government in Riau, it has long been an essential source of the regional revenue [48]. On the other hand, the development of peatland caused serious damages to the peatland ecosystem that triggered various impacts on the physical-environment status of peatland. Most of the problems were connected to the potential long-term damages of peatland ecosystems and the decrease of the welfare of affected people. Even worse, people who were not related to peatland development, e.g., those who did not have or were excluded from estate activities, have only seen negative impacts on their environment without directly receiving the economic benefit. The high interdependency of the problems formed various actor interventions. Some argued that the solution must be started from a small scale (community) level, while others believed that the interventions must be begun by designing policies that accommodate all problems. Thus, the complexity and interdependency of the problems have attracted various actors to take measures based on their interpretation of the problems and their interconnectedness [36].

\subsubsection{Solution Set}

Solutions offered by various actors were determined from the point of view of each actor in looking at the problem [36]. Measures such as the forest moratorium policies, strengthening government institutions to deal with fires, empowering economic capacity of the local community, and dealing practically with local level problems were some of the notable solutions offered by the actors. These various measures seem able to solve the complex problems of the Riau peatland. However, the extent to which the solution addresses the entire problem is still arguable and hard to define [36]. For example, a conflict between the community and a company that was triggered by a different interpretation of the design and use of canal block [82] shows that the solution was not easy to be set. Also, the inability of the measures taken by BRG to avoid reoccurring fires in their demonstration plots (see [66]) indicates a similar thing. Occasionally, the solutions set also caused a feedback effect. In relation to the scale, a solution designed to deal with fires in a village by blocking canals, for instance, had also caused the damages to the plantation to worsen due to the increase of the drying out process of water from the plantation into the canals, especially in which the canal was constructed without considering the relation to bigger canal systems. Thus, the solutions must be reformulated to meet all problems.

Therefore, peatland problems are complex and interrelated. The main issues discussed by actors have been the fires and deforestation that have occurred for several decades with massive consequences. Peat subsidence is still hardly noted even though its impacts are severe and the coverage area is huge. Indeed, due to the interconnectedness of the problems, interventions directed to solve one problem will affect others. This assumption also works for peat subsidence. However, peatlands problems need to be solved entirely and comprehensively. Therefore, the ability of actors to deal with this combined problem is really needed.

\subsection{Can the Government, NGOs, and Communities Manage Peat Subsidence Using Their Measures?}

To avoid the extensive consequences of peat subsidence and other problems, the governments from all levels, environmental and development NGOs, and communities have taken numerous measures (see Table 2). Amid all measures, those taken based on peat subsidence as the main concern were still limited, due to lack of knowledge or awareness from the actors. Because peat subsidence is a slow-onset disaster, it was not mentioned in any government documents. The measures to address peatland problems were not optimal because little attention was paid to the impacts peatland had 
over time in a vast coverage area and its important role in worsening other peatland problems cannot be discovered.

Beyond the lack of attention to peat subsidence, measures taken by all actors could be seen as a quick and partial solution for peatland problems. Measures were mostly designed by considering current impacts of peatland development on peatland ecosystem and affected people. Unfortunately, many interventions were designed mainly based on each actor's understanding of the problems, which somehow could not be linked to other measures taken by other actors. Consequently, those measures could not be combined or be complementary. To deal with the complex and interrelated problems of peatland, the complementary measures originated from all involved actors are needed [83].

Thanks to BRG through peatland restoration activities, opportunities for different actors to collaborate more intensively in making measures were opened. Restoration activities indeed are not a new way of managing peatland in Indonesia [84]. Previously, the restoration was arranged by an individual or a group of actors based on their resources. By the establishment of BRG, activities to restore peatland were rather organized and various actors have been involved. Consequently, some collaborations between actors have also been initiated. The collaborations between BRG and local environmental NGOs from the beginning of the designing of restoration programs up to the implementation of the programs shows that intensive interactions among such actors have been formed. The extensive knowledge of such NGOs about detailed peatland problems in a particular area and experience in designing solution-based activities for communities were their keys to be involved. From the NGOs side, their need to maintain their activities, improve their knowledge of peatland issues, and enhance their ability to manage peatland had pushed them to collaborate with other actors, including BRG. The need for knowledge and resource sharing has built relationships among the actors [85]. In practice, the collaborations have been started from activities to rewet the peatland, which is the priority activity of BRG to restore peatland. The rewetting through blocking of drainage canals is the way to control the balance of the water table $[84,86]$. For peatland in Riau, in which peat subsidence and fires are triggered by the unstable water table $[9,10,17]$, these activities might reduce the acceleration of sinking.

The ways the environmental NGOs supported the restoration agenda were also beyond the activities designed by BRG. Some of them initiated measures that were not handled by BRG or other government institutions yet by expanding their advocacy activities into knowledge-based actions. For instance, Jikalahari and Wetlands International Indonesia conducted workshops on peatland restoration and peat fire preparedness to share their knowledge of the peatland rewetting process and water table management, attended by the local community, NGOs, and MPAs. Wetlands International Indonesia supported BRG's 3R approach by providing funding for communities in the targeted areas of BRG through the Indonesian Peatland Partnership Fund (IPPF) program. These supporting measures can be seen as favorable to highlight the problems. Measures outside the collaborative works but needed by the government can be complementary to the government's measures [83].

The mentioned measures, both collaborative and complementary, seem likely to continue since they are fully supported by communities. Measures initiated by local environmental NGOs and the governments with communities at the village or community level could be effectively directed to deal with the core problems based on detailed information provided by communities. Supports from communities to implement the measures had also increased the opportunity to deal with the problems. Some measures directed to manage the balance of the water table in the smallholder plantation through the participation of communities indicated that they worked directly to fight current impacts and prevent drivers of peat subsidence. Therefore, by working with communities who own the consequences and are the target of interventions, the measures can lead to the root of the problems. 
All types of actors had tried to deal with peatland problems. Some measures were taken individually, while others were taken collaboratively. Some actors interacted with others and initiated collaborative works in an effort to adapt to their limited knowledge and resources to take action, expand their ability to influence other actors' activities, and enhance the output of solutions. These ways could increase the kinds and effectiveness of measures. These findings support the notion Mohammed and Inoue [28] stated that measures from state and non-state actors are substantial in dealing with problems. In the context of peat subsidence, even though limited because of problem interconnectedness, measures to deal with other problems intersected with peat subsidence. Even though they are not yet effective enough to prevent peat subsidence, the measures could slightly delay peat subsidence.

To conclude, this paper shows that interventions taken by both types of actors work for dealing with current problems, such as fires damages to canal and plantation. In addition, peatland restoration programs that were done collaboratively by different actors seem promising if applied in similar peatland areas in Indonesia or around the world where there are similar characteristics to the case study areas. However, one notable concern is that to optimize measures to deal with peatland problems, the comprehensive measures based on the peatland ecosystem unit must be thought through, which has not yet been entirely considered by current measures.

\section{Conclusions}

This paper analyses the types of problems that come with peat subsidence and interventions of various actors to deal with it. This paper shows it is clear that land subsidence in peatland areas is a matter of human behavior. The massive exploitation of peatland for economic and non-food related activities has triggered severe peatland problems, such as massive deforestation, fires, and peat subsidence, followed by costly consequences to the physical environment and socioeconomic status of peatland and affected people. In the case of the absence of proper interventions, the massive consequences of peatland development will stand still. Severe problems, such as the loss of peatland ecosystem and biodiversity, huge fires, the damages to the plantation, followed by the decrease in the economic status of affected people, and the land conflicts between community and company will be repeated. The constant multi-dimensional impacts, interdependency of the problems, and some solutions that might trigger other problems have shown that peatland problems look like a wicked problem.

Among all problems, peat subsidence is one of the most severe but least recognized issues. Peat subsidence and other problems are interrelated and driven by various sources. Peat subsidence may trigger more complex problems since it leads to and is led by other peatland problems $[5,9,12,17]$. Even though peat subsidence happens on a massive scale for an extended period and undermines the income earning capacity of people [9,55], peat subsidence in itself has never been a top concern of actors in managing peatland. The most commonly and intensely debated issues are peat fires and deforestation, which led to a massive loss of ecosystem, serious health problems, and frequent land tenure conflicts between community and company $[14,49,66,68,69,81]$. Regional and international impacts of fires have attracted public attention that covered the issue of peat subsidence. It is worsened by the fact that the consequences of peat subsidence for peatland and affected people can only be discovered after a long period of sinking. As a consequence of their hidden status, peat subsidence debates often came later on or as a part of other issues. Later, the lack of attention to peat subsidence together with other peatland problems prevented the problem from being solved. 
To deal with severe peatland problems, the case study highlights several interventions taken by the government from various levels, environmental and development NGOs, and communities. In a general pattern, the governments provided policies and worked on practical measures to manage risks [21,30]; NGOs supported the governments' measures through their knowledge of problems at a local level [33]; and, communities initiated small-scale community measures and ensured measures from other actors were accepted and maintained. In some cases, measures taken by these actors to deal with peatland problems in the areas near the concessions of private actors were also supported by some companies. For instance, with a limited involvement, some private sectors became involved voluntarily in developing MPA and restoring peatland in their concession [73]. On the other hand, private sectors were also obliged to restore peatland in their concessions [56]. Therefore, this shows that regulations issued by the national government that push private sectors to actively support the governments' program as well as initiatives of other actors to rehabilitate peatland have been able to trigger the companies to take actions.

Some of the measures were designed collaboratively, while others were designed differently. The different measures taken by the actors were driven by their dissimilar interpretation of the problems [36]. So the success of collaborative measures to manage some problems and direct the solutions close to the root of problems underlines the importance of actors to engage actively in activities to solve peatland issues.

Thanks to peatland restoration activities, the attention of all actors to the multi-faceted peatland problems has been improving and the resources have been distributed more proportionally based on the degree of the problem. Various peatland problems are in process of being solved, generally because of an increase in the involvement of different actors outside the formal authority. Even though the activities were more focused on restoring damages caused by fires and the drainage canals, the peat subsidence issue has been slowly rising. Therefore, the peatland restoration agenda can be regarded as a point of departure to deal with complex peatland problems through a comprehensive measure and collaboration of various actors. The restoration agenda by bringing various actors into collaborative actions can be seen as promising to the complex peatland problems. In the case study area, the collaboration between BRG, local government, environmental NGOs, and other actors increased the variety and quality of the measures. Therefore, the notion Lewis [87] stated that the government and NGOs could be constructive partners is supported by these findings. At the same time, it supports the idea of Roberts [40], stating that the collaboration might push the ability of each actor into the optimum level to create better outputs.

To conclude, it is unquestionable that the challenge to keep the productivity and sustainability of peatland is huge. The rise of economic demand for commodities on peatland and the target of the national government to intensify the use of peatland for economic purposes will leave peatland being exploited. The extent to which various actors can properly keep and use peatland will determine the degree of risk of peatland. An approach that is oriented to actor-centered rather promising to deal with peatland problems that look like wicked problems. However since not all of the problems could be solved and their interconnectedness is strong, a comprehensive approach to deal with all peatland problems at one time is needed. All problems must be considered, including peat subsidence.

Funding: This research received no external funding.

Acknowledgments: The author would like to acknowledge Annelies Zoomers and Tejo Spit for their constructive discussion on this paper. The author also thank all interviewees for sharing their experience. Finally, the author would like to thank four anonymous reviewers for their constructive input to the final version.

Conflicts of Interest: The author declares no conflict of interest. 


\section{Appendix A}

Table A1. List of selected actors.

\begin{tabular}{|c|c|}
\hline Selected Actor & Explanation \\
\hline \multicolumn{2}{|l|}{ A. Government (national, provincial, local) } \\
\hline 1. The Indonesian National Board for Disaster Management (BNPB) & National government \\
\hline 2. The Ministry of Environment and Forestry (MoEF) & National government \\
\hline 3. The Peatland Restoration Agency (BRG) & National government \\
\hline 4. The Ministry of National Development Planning/National & \\
\hline Development Planning Agency (Bappenas) & National government \\
\hline 5. Riau Province Government & Provincial government \\
\hline 6. The Provincial Board for Disaster Management (BPBD Provinsi) & Provincial government \\
\hline 7. District/City Board for Disaster Management (BPBD & Local government \\
\hline $\begin{array}{l}\text { Kabupaten/Kota) } \\
\text { 8. The Forestry office of Indragiri Hilir }\end{array}$ & Local government \\
\hline 9. The Environmental office (BLH) of Indragiri Hilir & Local government \\
\hline 10. The Spatial Planning Board (Bappeda) of Indragiri Hilir & Local government \\
\hline \multicolumn{2}{|l|}{ B. NGO (environmental and development NGO) } \\
\hline 11. Walhi Indonesia & National NGO; headquarter is outside Riau but work in Riau \\
\hline 12. Greenpeace Indonesia & National NGO; headquarter is outside Riau but work in Riau \\
\hline 13. WWF Indonesia & National NGO; headquarter is outside Riau but work in Riau \\
\hline 14. Indonesian Society for Disaster Management (MPBI) & National NGO \\
\hline 15. Foundation for Sustainable Development (YPB) & National NGO \\
\hline 16. Wetlands International Indonesia & National NGO; headquarter is outside Riau but work in Riau \\
\hline 17. Walhi Riau & Local NGO and work in Riau \\
\hline 18. Hutan Riau & Local NGO and work in Riau \\
\hline 19. Greenpeace Riau office & Local NGO and work in Riau \\
\hline 20. Jaringan Kerja Penyelamat Hutan Riau (Jikalahari) & Local NGO and work in Riau \\
\hline 21. LSM Rupari & Local NGO and work in Riau \\
\hline 22. Yayasan Mitra Insani (YMI) & Local NGO and work in Riau \\
\hline C. Local community & Local communities in Indragiri Hilir District \\
\hline
\end{tabular}

\section{References}

1. Xu, J.; Morris, P.J.; Liu, J.; Holden, J. PEATMAP: Refining Estimates of Global Peatland Distribution Based on a Meta-Analysis. Catena 2018, 160, 134-140. [CrossRef]

2. Joosten, H.; Clarke, D. Wise Use of Mires and Peatlands-Background and Principles Including a Framework for Decision-Making; International Mire Conservation Group and International Peat Society: Devon, UK, 2002; ISBN 951-97744-8-3.

3. Joosten, H. Peatlands, Climate Change Mitigation and Biodiversity Conservation: An Issue Brief on the Importance of Peatlands for Carbon and Biodiversity Conservation and the Role of Drained Peatlands as Greenhouse Gas Emission Hotspots; Nordic Council of Ministers: Copenhagen, Denmark, 2015; ISBN 978-92-893-4168-4.

4. Hooijer, A.; Page, S.; Canadell, J.G.; Silvius, M.; Kwadijk, J.; Wosten, H.; Jauhiainen, J. Current and Future $\mathrm{CO}_{2}$ Emissions from Drained Peatlands in Southeast Asia. Biogeosciences 2010, 7, 1505-1514. [CrossRef]

5. Couwenberg, J.; Hooijer, A. Towards Robust Subsidence-based Soil Carbon Emission Factors for Peat Soils in South-east Asia, with Special Reference to Oil Palm Plantations. Mires Peat 2013, 12, 1-13.

6. Urák, I.; Hartel, T.; Gallé, R.; Balog, A. Worldwide Peatland Degradations and the Related Carbon Dioxide Emissions: The Importance of Policy Regulations. Environ. Sci Policy 2017, 69, 57-64. [CrossRef]

7. Dohong, A.; Aziz, A.A.; Dargusch, P. A Review of the Drivers of Tropical Peatland Degradation in South-East Asia. Land Use Policy 2017, 69, 349-360. [CrossRef]

8. Page, S.E.; Siegert, F.; Rieley, J.O.; Boehm, H.V.; Jaya, A.; Limin, S. The Amount of Carbon Released from Peat and Forest Fires in Indonesia during 1997. Nature 2002, 420, 61-65. [CrossRef] [PubMed]

9. Hooijer, A.; Page, S.; Jauhiainen, J.; Lee, W.A.; Lu, X.X.; Idris, A.; Anshari, G. Subsidence and Carbon Loss in Drained Tropical Peatlands. Biogeosciences 2012, 9, 1053-1071. [CrossRef]

10. Saputra, E.; Hartmann, T.; Zoomers, A.; Spit, T. Fighting the Ignorance: Public Authorities' and Land Users' Responses to Land Subsidence in Indonesia. Am. J. Clim Chang. 2017, 6, 1-21. [CrossRef]

11. Wösten, J.H.M.; Clymans, E.; Page, S.E.; Rieley, J.O.; Limin, S.H. Peat-Water Interrelationships in a Tropical Peatland Ecosystem in Southeast Asia. Catena 2008, 73, 212-224. [CrossRef] 
12. Thorburn, C.C.; Kull, C.A. Peatlands and Plantations in Sumatra, Indonesia: Complex Realities for Resource Governance, Rural Development and Climate Change Mitigation. Asia Pac. Viewp. 2015, 56, 153-168. [CrossRef]

13. Evers, S.; Yule, C.M.; Padfield, R.; O'reilly, P.; Varkkey, H. Keep Wetlands Wet: The Myth of Sustainable Development of Tropical Peatlands-Implications for Policies and Management. Glob. Chang. Biol. 2017, 23, 534-549. [CrossRef]

14. Kieft, J.; Smith, T.; Someshwar, S.; Boer, R. Towards Anticipatory Management of Peat Fires to Enhance Local Resilience and Reduce Natural Capital Depletion. In Ecosystem-Based Disaster Risk Reduction and Adaptation in Practice; Renaud, F.G., Sudmeier-Rieux, K., Estrella, M.N.U., Eds.; Springer: Berlin, Germany, 2016; pp. 361-377, ISBN 978-3-319-43633-3.

15. Laura, C.; Pietro, T.; Luigi, T. Land subsidence in the Venetian Area: Known and Recent Aspects. G. Geol. Appl. 2005, 1, 5-11. [CrossRef]

16. Butler, L.; MacEwan, D.; Zhou, T.; Brock, A.; Jacobs, P.; Scheer, J.; Tumber, K. Update on Economic Impacts of Subsidence and Accretion in the Sacramento-San Joaquin Delta. Presented at the 60th Annual Conference of the Australian Agricultural \& Resource Economics, Canberra, Australia, 2-5 February 2016.

17. Schrier-Uijl, A.P.; Silvius, M.; Parish, F.; Lim, K.; Rosediana, S.; Anshari, G. Environmental and Social Impacts of Oil Palm Cultivation on Tropical Peat: A Scientific Review; Roundtable of Sustainable Palm Oil: Kuala Lumpur, Malaysia, 2013; pp. 131-168.

18. Shaw, R. The role of Nongovernmental Organizations in Earthquake Disaster Management: An Asian Perspective. Reg. Dev. Dialogue 2003, 24, 117-129.

19. Birkmann, J.; Buckle, P.; Jaeger, J.; Pelling, M.; Setiadi, N.; Garschagen, M.; Fernando, N.; Kropp, J. Extreme Events and Disasters: A Window of Opportunity for Change? Analysis of Organizational, Institutional and Political Changes, Formal and Informal Responses After Mega-Disasters. Nat. Hazards 2010, 55, 637-655. [CrossRef]

20. Perry, R.W.; Lindell, M.K. Volcanic Risk Perception and Adjustment in a Multi-Hazard Environment. J. Volcanol. Geoth. Res. 2008, 172, 170-178. [CrossRef]

21. Topno, P.N. Multi-stakeholder Support in Disaster Risk Governance in India. In Anonymous Disaster Risk Governance in India and Cross Cutting Issues; Pal, I., Shaw, R., Eds.; Springer: Berlin, Germany, 2018; pp. 127-142, ISBN 978-981-10-3310-0.

22. Biermann, F.; Kanie, N.; Kim, R.E. Global Governance by Goal-Setting: The Novel Approach of the UN Sustainable Development Goals. Curr. Opin. Environ. Sustain. 2017, 26, 26-31. [CrossRef]

23. Itoh, M.; Okimoto, Y.; Hirano, T.; Kusin, K. Factors Affecting Oxidative Peat Decomposition due to Land Use in Tropical Peat Swamp Forests in Indonesia. Sci. Total Environ. 2017, 609, 906-915. [CrossRef]

24. Warren, M.; Hergoualc'h, K.; Kauffman, J.B.; Murdiyarso, D.; Kolka, R. An Appraisal of Indonesia's Immense Peat Carbon Stock using National Peatland Maps: Uncertainties and Potential Losses from Conversion. Carbon Balance Manag. 2017, 12, 1-12. [CrossRef]

25. Galloway, D.; Jones, D.R.; Ingebritsen, S.E. Land subsidence in the United States; US Geological Survey: Reston, VA, USA, 1999.

26. Shi, X.; Xue, Y.; Wu, J.; Ye, S.; Zhang, Y.; Wei, Z.; Yu, J. Characterization of regional land subsidence in Yangtze Delta, China: The example of Su-Xi-Chang area and the city of Shanghai. Hydrogeol. J. 2008, 16, 593-607. [CrossRef]

27. Sloat, A. An Actor-Centred Approach to Multi-Level Governance: Expectations of Scotland's Role in Europe. Reg. Fed. Stud. 2002, 12, 156-180. [CrossRef]

28. Mohammed, A.; Inoue, M. Understanding REDD with Actor-Centered Power Approach: A Review. J. Biodivers Manag. 2016, 5, 1-8. [CrossRef]

29. Kumar, N. Disaster Risk Reduction: Importance of Responsibilities of States. In Disaster Risk Governance in India and Cross Cutting Issues; Pal, I., Shaw, R., Eds.; Springer: Berlin, Germany, 2018; pp. 85-101, ISBN 978-981-10-3309-4.

30. Bollin, C.; Cárdenas, C.; Hahn, H.; Vatsa, K.S. Disaster Risk Management by Communities and Local Governments; Inter-American Development Bank: New York, NY, USA, 2003.

31. Haque, M.S. The Changing Balance of Power Between the Government and NGOS in Bangladesh. Int. Political Sci. Rev. 2002, 23, 411-435. [CrossRef] 
32. Agarwal, B. Participatory Exclusions, Community Forestry, and Gender: An Analysis for South Asia and a Conceptual Framework. World Dev. 2001, 29, 1623-1648. [CrossRef]

33. Benson, C.; Twigg, J.; Myers, M. NGO Initiatives in Risk Reduction: An Overview. Disasters 2001, 25, $199-215$. [CrossRef]

34. King, D. Organisations in Disaster. Nat. Hazards 2007, 40, 657-665. [CrossRef]

35. Pandey, B.; Okazaki, K. Community-based Disaster Management: Empowering Communities to Cope with Disaster Risks. Reg. Dev. Dialogue 2005, 26, 52.

36. Howes, S.; Wyrwoll, P. Asia's Wicked Environmental Problems; Asian Development Bank Institute: Tokyo, Japan, 2012; pp. 1-49.

37. Rhodes, R.A. Understanding governance: Ten years on. Org. Stud. 2007, 28, 1243-1264. [CrossRef]

38. Biermann, F.; Stevens, C.; Bernstein, S.; Gupta, A.; Kabiri, N.; Kanie, N.; Levy, M.; Nilsson, M.; Pintér, L.; Scobie, M.; et al. Integrating Governance into the Sustainable Development Goals; Policy Brief \#3; United Nations University: Tokyo, Japan, 2014.

39. Beckert, J. Agency, Entrepreneurs, and Institutional Change. The Role of Strategic Choice and Institutionalized Practices in Organizations. Org. Stud. 1999, 20, 777-799. [CrossRef]

40. Roberts, N. Wicked Problems and Network Approaches to Resolution. Int. Pub. Manag. Rev. 2000, 1, 1-19.

41. Australian Public Service Commission. Tackling Wicked Problems: A Public Policy Perspective. Available online: https://www.apsc.gov.au/tackling-wicked-problems-public-policy-perspective (accessed on 17 April 2019).

42. Vervoort, J.; Ingram, J.; Ericksen, P.; Chaudhury, M.; Foerch, W.; Thornton, P.; Kristjanson, P. Multi-actor Scenarios to Build Capacity for Food Systems Governance at the Sub-continental Level. In Proceedings of the Earth System Governance conference, Lund, Sweden, 18-20 April 2012.

43. Yin, R.K. Case Study Research: Design and Methods; Sage Publications: Thousand Oaks, CA, USA, 2014.

44. Krueger, R.A. Focus Groups: A Practical Guide for Applied Research; SAGE Publications: Thousand Oaks, CA, USA, 1994.

45. Ritchie, J.; Spencer, L. Qualitative Data Analysis for Applied Policy Research. In The Qualitative Researcher's Companion; Huberman, A.M., Miles, M.B., Eds.; SAGE Publications: Thousand Oaks, CA, USA, 2002.

46. Rabiee, F. Focus-Group Interview and Data Analysis. Proc. Nutr. Soc. 2004, 63, 655-660. [CrossRef]

47. Pemerintah Provinsi Riau. Rencana Tata Ruang Wilayah Provinsi Riau Tahun 2018-2038 [Spatial Planning of Riau Province year 2018-2038]; Pemerintah Provinsi Riau: Pekanbaru, Riau, 2018.

48. Susanti, A.; Burgers, P. Oil Palm Expansion in Riau Province, Indonesia: Serving People, Planet, Profit? Background Paper to the 2011/2012 European Report on Development, Confronting Scarcity: Managing Water, Energy and Land for Inclusive and Sustainable Growth. 2012. Available online: https://ec.europa.eu/ europeaid/sites/devco/files/erd-consca-dev-researchpapers-susanti-burgers-20110101_en.pdf (accessed on 27 April 2019).

49. Uryu, Y.; Mott, C.; Foead, N.; Yulianto, K.; Budiman, A.; Takakai, F.; Nursamsu, S.; Purastuti, E.; Fadhli, N.; Hutajulu, C.M.B.; et al. Deforestation, Forest Degradation, Biodiversity Loss and $\mathrm{CO}_{2}$ Emissions in Riau, Sumatra, Indonesia; WWF Indonesia: Jakarta, Indonesia, 2008.

50. WWF Indonesia. The Eleventh Hour for Riau's Forests Two Global Pulp and Paper Companies will Decide Their Fate; WWF Indonesia: Jakarta, Indonesia, 2006.

51. Susanti, A.; Burgers, P. Oil palm expansion: Competing claim of lands for food, biofuels, and conservation. In Sustainable Food Security in the Era of Local and Global Environmental Change; Behnassi, M., Pollmann, O., Kissinger, G., Eds.; Springer: Dordrecht, The Netherlands, 2013; pp. 301-320.

52. MoAgr. Tree Crop. Estate Statistics of Indonesia 2015-2017: Palm Oil; Ministry of Agriculture Indonesia: Jakarta, Jakarta, 2017.

53. MoAgr. Tree Crop. Estate Statistics of Indonesia 2015-2017: Coconut; Ministry of Agriculture Indonesia: Jakarta, Jakarta, 2017.

54. Statistics Indonesia. Statistics of Forestry Production 2015; Statistics Indonesia: Jakarta, Indonesia, 2016.

55. Saputra, E.; Spit, T.; Zoomers, A. Living in a Bottomless Pit: Households Responses to Land Subsidence, an Example from Indonesia. J. Environ. Prot. 2019, 10, 1-21. [CrossRef]

56. BRG. Rencana Strategis Badan Restorasi Gambut 2016-2020; Badan Restorasi Gambut Indonesia: Jakarta, Indonesia, 2016. 
57. Ramdani, F.; Hino, M. Land Use Changes and GHG Emissions from Tropical Forest Conversion by Oil Palm Plantations in Riau Province, Indonesia. PLoS ONE 2013, 8, e70323. [CrossRef]

58. Busch, J.; Ferretti-Gallon, K.; Engelmann, J.; Wright, M.; Austin, K.G.; Stolle, F.; Turubanova, S.; Potapov, P.V.; Margono, B.; Hansen, M.C.; et al. Reductions in Emissions from Deforestation from Indonesia's Moratorium on New Oil Palm, Timber, and Logging Concessions. Proc. Natl. Acad. Sci. USA 2015, 1328-1333. [CrossRef]

59. MoFor. Rencana Kehutanan Tingkat Nasional (RKTN) Tahun 2011-2030; Ministry of Forestry Indonesia: Jakarta, Indonesia, 2011.

60. Margono, B.A.; Potapov, P.V.; Turubanova, S.; Stolle, F.; Hansen, M.C. Primary Forest Cover Loss in Indonesia over 2000-2012. Nat. Clim. Chang. 2014, 4, 730-735. [CrossRef]

61. Sizer, N.; Leach, A.; Minnemeyer, A.; Higgins, M.; Stolle, F.; Anderson, J.; Lawalata, J. Preventing Forest Fires in Indonesia: Focus on Riau Province, Peatland, and Illegal Burning. Available online: http://www.wri.org/ blog/2014/04/preventing-forest-firesindonesia-focus-riau-province-peatland-and-illegal-burning (accessed on 25 August 2018).

62. Miettinen, J.; Liew, S. Connection between Fire and Land Cover Change in Southeast Asia: A Remote Sensing Case Study in Riau, Sumatra. Int. J. Remote Sens. 2005, 26, 1109-1126. [CrossRef]

63. Glover, D.; Jessup, T. Indonesia's Fires and Haze: The Cost of Catastrophe; ISEAS; IDRC: Singapore, 2006.

64. Suyanto, S.; Applegate, G.; Permana, R.P.; Khususiyah, N.; Kurniawan, I. The Role of Fire in Changing Land Use and Livelihoods in Riau-Sumatra. Ecol. Soc. 2004, 9, 1-11. [CrossRef]

65. Prayoto; Ishihara, M.I.; Firdaus, R.; Nakagoshi, N. Peatland Fires in Riau, Indonesia, in Relation to Land Cover Type, Land Management, Landholder, and Spatial Management. J. Environ. Prot. 2017, 8, 1312-1332. [CrossRef]

66. BNPB. Data Bencana Indonesia Tahun 2015; Badan Nasional Penanggulangan Bencana Indonesia: Jakarta, Indonesia, 2016.

67. Jikalahari. Catatan Akhir Tahun 2018: Hutan Binasa, Banjir Melanda; Jikalahari: Pekanbaru, Riau, 2018.

68. Herawati, H.; Santoso, H. Tropical Forest Susceptibility to and Risk of Fire under Changing Climate: A Review of Fire Nature, Policy and Institutions in Indonesia. For. Policy Econ. 2011, 13, 227-233. [CrossRef]

69. Tacconi, L. Fires in Indonesia: Causes, Costs and Policy Implications; Cifor: Bogor, Indonesia, 2003.

70. Evans, C.D.; Williamson, J.M.; Kacaribu, F.; Irawan, D.; Suardiwerianto, Y.; Hidayat, M.F.; Lauren, A.; Page, S.E. Rates and Spatial Variability of Peat Subsidence in Acacia Plantation and Forest Landscapes in Sumatra, Indonesia. Geoderma 2019, 338, 410-421. [CrossRef]

71. Wosten, J.; Ismail, A.; Van Wijk, A. Peat Subsidence and Its Practical Implications: A Case Study in Malaysia. Geoderma 1997, 78, 25-36. [CrossRef]

72. MoEF. Managing Peatlands to Cope with Climate Change: Indonesia's Experience; Ministry of Environment and Forestry Republic of Indonesia: Jakarta, Indonesia, 2018.

73. The Jakarta Post. APP Sinar Mas Village Program Gets Govt's Appreciation. Available online: https://www. thejakartapost.com/adv/2017/12/14/app-sinar-mas-village-program-gets-govts-appreciation.html (accessed on 17 April 2019).

74. Mongabay. Asian Games, Riau Perpanjang Status Siaga Darurat Karhutla. Available online: https: //www.mongabay.co.id/2018/05/30/asian-games-riau-perpanjang-status-siaga-darurat-karhutla/ (accessed on 17 April 2019).

75. Ni'mah, N.; Herdiansyah, H.; Soesilo, T.; Mutia, E. Strategy for Increasing the Participation of Masyarakat Peduli Api in Forest Fire Control. Iop Conf. Ser. Earth Environ. Sci. 2018, 126, 1-9. [CrossRef]

76. BRG. BRG Lanjutkan Restorasi Gambut di Kepulauan Meranti, Riau. Available online: https://brg.go.id/brglanjutkan-restorasi-gambut-di-kepulauan-meranti-riau/ (accessed on 31 April 2018).

77. JawaPos. Bangun Sekat Kanal di Dumai, Badan Restorasi Gambut Anggarkan Rp 1,5 M. Available online: https://www.jawapos.com/jpg-today/20/09/2018/bangun-sekat-kanal-di-dumai-badan-restorasigambut-anggarkan-rp-15-m (accessed on 28 December 2018).

78. Jikalahari. Catatan Akhir Tahun (CAT) 2017; Jikalahari: Pekanbaru, Riau, 2017.

79. WWF Indonesia. RSPO Annual Communications of Progress 2016; WWF Indonesia: Jakarta, Indonesia, 2016.

80. FAO. Wetlands International. Peatlands: Guidance for Climate Change Mitigation through Conservation, Rehabilitation and Sustainable Use; FAO and Wetlands International: Rome, Italy, 2012.

81. Scale Up. Catatan Konflik Tenurial Provinsi Riau tahun 2017; Scale Up: Pekanbaru, Riau, 2017. 
82. Jikalahari. Aparat Hukum Usut Tuntas Pengrusakan Sekat Kanal oleh PT Surya Dumai Agrindo di Desa Buruk Bakul. Available online: http://jikalahari.or.id/kabar/rilis/aparat-hukum-usut-tuntas-pengrusakansekat-kanal-oleh-pt-surya-dumai-agrindo-di-desa-buruk-bakul/ (accessed on 25 October 2018).

83. Espia, J.C.P.; Fernandez, P., Jr. Insiders and Outsiders: Local Government and NGO Engagement in Disaster Response in Guimaras, Philippines. Disasters 2015, 39, 51-68. [CrossRef]

84. Suryadiputra, I.N.N.; Dohong, A.; Waspodo, R.S.B.; Muslihat, L.; Lubis, I.R.; Hasudungan, F.; Wibisono, I.T.C. A Guide to the Blocking of Canals and Ditches in Conjunction with the Community; Wetlands International Indonesia Programme: Bogor, Indonesia, 2005.

85. Bebbington, A.; Farrington, J.; Lewis, D.J.; Wellard, K. Reluctant Partners? Non-Governmental Organizations, the State and Sustainable Agricultural Development; Routledge: New York, NY, USA, 2005.

86. Page, S.; Hosciło, A.; Wösten, H.; Jauhiainen, J.; Silvius, M.; Rieley, J.; Ritzema, H.; Tansey, K.; Graham, L.; Vasander, H.; et al. Restoration Ecology of Lowland Tropical Peatlands in Southeast Asia: Current Knowledge and Future Research Directions. Ecosystems 2009, 12, 888-905. [CrossRef]

87. Lewis, D. The Management of Non-Governmental Development Organizations: An. Introduction; Routledge: New York, NY, USA, 2004.

(C) 2019 by the author. Licensee MDPI, Basel, Switzerland. This article is an open access article distributed under the terms and conditions of the Creative Commons Attribution (CC BY) license (http://creativecommons.org/licenses/by/4.0/). 